\title{
Distribution of whitemouth croaker Micropogonias furnieri in relation to environmental factors at the Río de la Plata estuary, South America
}

\author{
Andres J. Jaureguizar ${ }^{1,2, *}$, Jose Bava ${ }^{1,3}$, Claudia R. Carozza ${ }^{2}$, Carlos A. Lasta ${ }^{2}$ \\ ${ }^{1}$ CONICET - Consejo Nacional de Investigaciones Científicas y Técnicas, Avda. Rivadavia 1917, 1033 Ciudad de Buenos Aires, \\ Argentina \\ ${ }^{2}$ INIDEP — Instituto Nacional de Investigación y Desarrollo Pesquero, Paseo Victoria Ocampo 1, 7600 Mar del Plata, \\ Argentina \\ ${ }^{3}$ IAFE - Instituto de Astronomia y Fisica del Espacio, Ciudad Universitaria, Pabellon IAFE, CC67 Suc. 28, \\ 1428 Ciudad de Buenos Aires, Argentina
}

\begin{abstract}
The age-class distribution of the whitemouth croaker Micropogonias furnieri and its relationship to environmental factors was evaluated from 278 stations sampled between 1993 and 1999 during early winter and spring within the Rio de la Plata estuary $\left(36^{\circ} \mathrm{S}, 56^{\circ} \mathrm{W}\right)$. A detrended canonical correspondence analysis (DCCA) was used to define sampling station groups based on age structure of whitemouth croaker, and to estimate their association with depth, type of substrate, temperature and salinity of surface and bottom waters. Complementary information for surface temperature and location of the turbidity fronts was derived from NOAA-14-AVHRR imagery obtained in 1999. Results indicated that bottom salinity has a major influence on the spatial distribution pattern of $M$. furnieri, and that distinct preferences for different salinities by the various age-classes of this species result in a differential distribution pattern along the main axis of the estuary. In both seasons, turbidity fronts were located at the inner central area of the estuary and showed a close fit with the distribution of the youngest age-classes.
\end{abstract}

KEY WORDS: Micropogonias furnieri $\cdot$ Age-classes $\cdot$ Environmental factors $\cdot$ Río de la Plata $\cdot$ Estuary Resale or republication not permitted without written consent of the publisher

\section{INTRODUCTION}

The geographical distribution of whitemouth croaker Micropogonias furnieri extends from Veracruz, Mexico $\left(20^{\circ} 20^{\prime} \mathrm{N}\right)$ to El Rincón, Argentina $\left(41^{\circ} 00^{\prime} \mathrm{S}\right)$ (Cousseau \& Perrota 2000). M. furnieri is one of the 7 species of Sciaenidae inhabiting bottom waters of the Río de la Plata estuary $\left(36^{\circ} \mathrm{S}, 56^{\circ} \mathrm{W}\right)$ (Cousseau 1985). This species supports the traditional fisheries of the Argentinean, Brasilian and Uruguayan coastal region (Otero \& Ibañez 1986, Haimovici et al. 1989, Lasta \& Acha 1996), and the whitemouth croaker may be considered as one of the most commercially important bottom fish of the Río de la Plata (Lasta \& Acha 1996) and the entire Uruguayan Atlantic coastline (Norbis 1995). The whitemouth croaker fishery in the Río de la Plata estuary is mainly artisanal, with fish being caught mostly in winter in the Samborombon Bay area of Argentina (Mianzan et al. 2001), and during spring and summer in the Santa Lucia area of Uruguay (Norbis et al. 1992, Norbis 1995) (Fig. 1). The Río de la Plata estuary, including inshore areas of Samborombon Bay and the Santa Lucia River, represents the principal spawning and nursery area of $M$. furnieri in the region (Lasta 1995, Macchi \& Christiansen 1996, Acha 1999).

Several aspects of this species' life history have been well studied, including its food and feeding habitat (Puig 1986, Sánchez et al. 1991, Hozbor \& Garcia de la Rosa 2000, Giberto 2001), age and growth (Cotrina \& Lasta 1986), reproductive biology (Macchi \& Christensen 1996, Macchi \& Acha 1998, Acha et al. 1999), nursery areas (Lasta 1995), and length distribution (Cotrina 1986, Cousseau et al. 1986, Díaz de Astarloa et al. 1997, Carozza \& Cotrina 1998). However, there is 


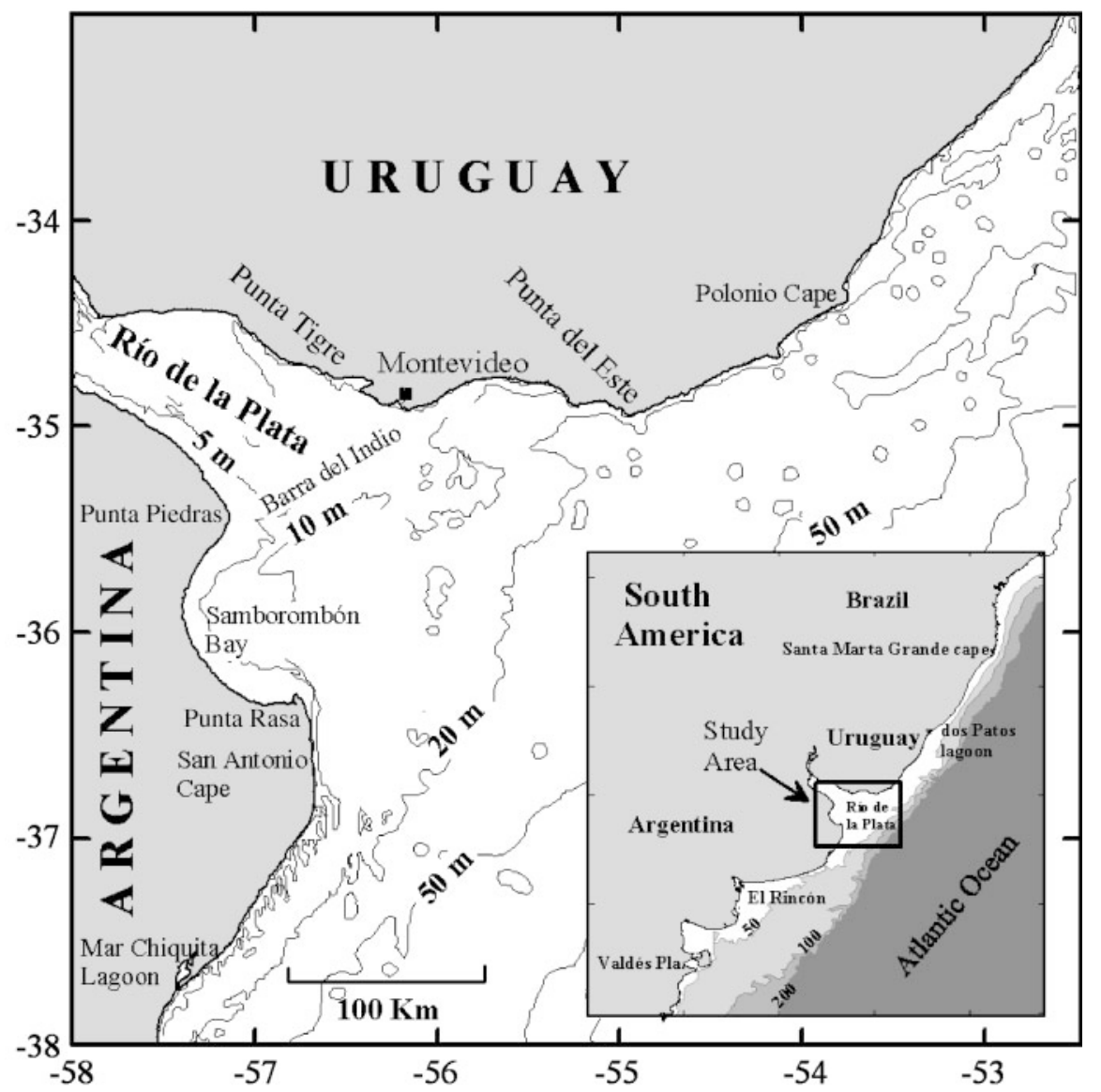

Fig. 1. Location and bathymetry of the study area

western South American coast $\left(36^{\circ} \mathrm{S}^{\prime}\right.$, $56^{\circ} \mathrm{W}$ ) (Fig. 1). The physical characteristics of the Río de la Plata estuary, which has a microtidal amplitude (Balay 1961) and small seasonality in the discharge of continental water, generate a stable environmental gradient (Mianzan et al. 2001). A shallow bar across the river running along a line from Punta Piedras to Montevideo, known as Barra del Indio, divides the estuary into an inner and outer region (CARP 1989). The inner region represents a fluvial regime and is entirely freshwater, with a depth range of 1 to $5 \mathrm{~m}$. The outer region is predominantly mixohaline with an area of approximately $38000 \mathrm{~km}^{2}$ (Mianzan et al. 2001) and a depth range of 5 to $15 \mathrm{~m}$. Its boundary with the continental shelf water, defined by the 27 to 30 psu surface isohaline, depends on the dynamics of the estuarine waters (Guerrero et al. 1997a). The penetration of marine water as a lower layer into the riverine system occurs as a salt wedge, and defines an area of strong vertical stratification (Guerrero et al. 1997a, Framiñan et al. 1999). Winds and discharge influence the surface salinity pattern, while bot-

little known about the manner in which environmental factors determine the distribution of whitemouth croaker within the estuary.

The specific objectives of this study were to determine differences in spatial distribution patterns among age-classes of Micropogonias furnieri in early winter and spring, and to examine the relationships between age-class distribution patterns and environmental factors. This study represents the first attempt to estimate the influence of environmental factors on the spatial distribution of $M$. furnieri age-classes within the Río de la Plata estuary. Understanding the dynamics between fish populations and important habitats is fundamental for the effective management of fish populations. Defining the preferred habitats of the different whitemouth croaker age-classes within the estuary by understanding the underlying mechanisms will allow for more effective management of the fishery.

\section{MATERIALS AND METHODS}

Description of the study area. The Río de la Plata is an extensive shallow coastal-plain estuary on the tom salinity is primarily controlled by bathymetry (Guerrero et al. 1997a).

The zone of greatest vertical salinity stratification, associated with the landward limit of the salt intrusion into the estuary (Guerrero et al. 1997a), correlates well with the region of highest turbidity (Framiñan \& Brown 1996). The estuarine turbidity front is an area of enhanced plankton concentration (Mianzan et al. 2001) and prey abundance for Micropogonias furnieri, including prey types such as Mactra isabellana (Giberto 2001) and Myscidacea (Dr. F. Ramirez pers. comm.).

Sampling and data analysis. Specimens of Micropogonias furnieri and oceanographic data were obtained from the Río de la Plata estuary in early winter and spring, from 1993 to 1999, during fisheries evaluation cruises of the Instituto Nacional de Investigación y Desarrollo Pesquero (INIDEP) (Fig. 1).

Whitemouth croaker specimens were collected in 124 bottom-trawl sets in early winter (July 1993, 1994, 1995, 1996, 1998 and June 1999) and 154 bottom-trawl sets in spring (November, from 1994 to 1999) (Table 1).

Standard bottom trawls used an Engel trawl (200 mm mesh in the wings and $120 \mathrm{~mm}$ mesh in the cod ends, 
Table 1. List of cruises conducted in the Río de la Plata estuary. Month (M) and total number of stations sampled (Stn)

\begin{tabular}{|ccccc|}
\hline \multirow{2}{*}{ Year } & \multicolumn{2}{c}{ Early winter } & \multicolumn{2}{c|}{ Spring } \\
& M & Stn & M & Stn \\
\hline 1993 & 07 & 13 & - & - \\
1994 & 07 & 19 & 11 & 34 \\
1995 & 07 & 17 & 11 & 37 \\
1996 & 07 & 8 & 11 & 31 \\
1997 & - & - & 11 & 14 \\
1998 & 07 & 36 & 11 & 24 \\
1999 & 06 & 31 & 11 & 14 \\
\hline
\end{tabular}

$4 \mathrm{~m}$ vertical opening and $15 \mathrm{~m}$ horizontal aperture) operating at 4 knots for 15 min per set.

At each station, the length-frequency distribution of Micropogonias furnieri was estimated. Total length (TL), measured to the nearest $\mathrm{cm}$, was recorded for each specimen. The length-age tables (Cotrina \& Lasta 1986, C. P. Cotrina \& C. R. Carozza unpubl. data) from specimens obtained in this area were used to estimate the abundance (thousands of ind. nautical [n] mile ${ }^{-2}$ ) for each age class (Age $0+$ to Age $>4+$ ).

Temperature and salinity at each station were measured using a CTD (conductivity-temperature-depth profiler) with a sampling rate of 2 scans $\mathrm{s}^{-1}$ and a lowering speed of $0.5 \mathrm{~m} \mathrm{~s}^{-1}$. Data were reduced to $1 \mathrm{~m}$ vertical resolution, with a precision of $\pm 0.03^{\circ} \mathrm{C}$ for temperature and $\pm 0.05 \mathrm{psu}$ for salinity. Bottom temperature and salinity values for each sampling season were used to define the horizontal distribution of these parameters.

Information on bottom sediment characteristics (mud, sand, and shell and sand) for each station was obtained from data presented by Giberto (2001). Although these data are independent of this study, the sampling area was the same and the spatial resolution of sediment sampling was fine enough to obtain general information suitable for our analysis.

For each season, the abundance of each age class per station was used to define groups of stations based on similar age composition (spatial ordination). Abundance data were $\log _{10}(x+1)$-transformed to reduce the effect of dominance by certain age-classes. Station groups and estimation of their association with depth, type of substrate, temperature and salinity of surface and bottom waters were identified using a detrended canonical correspondence analysis (DCCA). The 'arch effect' (Gauch 1982) was apparent in the initial correspondence analysis, suggesting the need for detrending. We detrended by second-order polynomials, which avoids the destruction of ecologically meaningful information which might occur when detrending by segments (Jongman et al. 1995). The significance test was based on the Monte Carlo permutation test $\left(10^{3}\right.$ permutations) for the sum of all eigenvalues. The significance of the relationship between gradients and individual environment variables was evaluated by means of a $t$-test.

NOAA-14-AVHRR imagery from 1999 was used as complementary information for surface temperature and turbidity-front distribution. The satellite data images were corrected to Mercator projection with a pixel resolution of $1 \times 1 \mathrm{~km}$, and clouds were removed using a combination of threshold values from Bands 1 and 4. Land was masked using a mask image produced for this area, and a general atmospheric correction was applied to the Optic Bands 1 and 2 of each image. To achieve this, the mean of the lowest $20 \%$ of the reflectance data was used as a dark object value. Following the methodology described by Framiñan \& Brown (1996), a total of 40 useable daytime images allowed us to determine 15 positions of the turbidity front for winter and 25 positions for spring. Sea surface temperature was computed using a multichannel algorithm for the Infrared Bands 4 and 5.

\section{RESULTS}

\section{Micropogonias furnieri age composition within the estuary}

Age Class 0+ was the most abundant (27.5\%) of the Micropogonias furnieri population in the estuary over the entire sampling period. However, the population structure of $M$. furnieri showed a clear seasonal difference; juvenile Ages $0+$ to 2+ dominated in early winter while adults Age 4+ dominated in spring (Fig. 2).

\section{Environmental conditions}

Bottom and surface temperature showed a weak horizontal gradient in both seasons (Figs. 3A,B \& 4A,B). The lowest values occurred in the inner (riverine) stations for early winter, while in spring the lowest values occurred in the outer (mixohaline) stations. Mean surface temperature was only $1^{\circ} \mathrm{C}$ above the bottom mean for both seasons (Table 2).

Bottom salinity varied from 0 (upstream of Punta Tigre and at Punta Piedras, Fig. 1) to 30 psu (outer stations of the estuary). Isohalines showed a SW-NE orientation for both periods. However, in early winter the Argentine coast was more saline with higher horizontal gradients than the Uruguayan coast (Fig. 3C). In spring the Uruguayan coast was more saline with a higher horizontal gradient than the Argentine coast, and the fresher waters (waters with salinity values lower than $30 \mathrm{psu}$ ) extend southward along the Argentine coast (Fig. 4C). For both seasons, the region with 

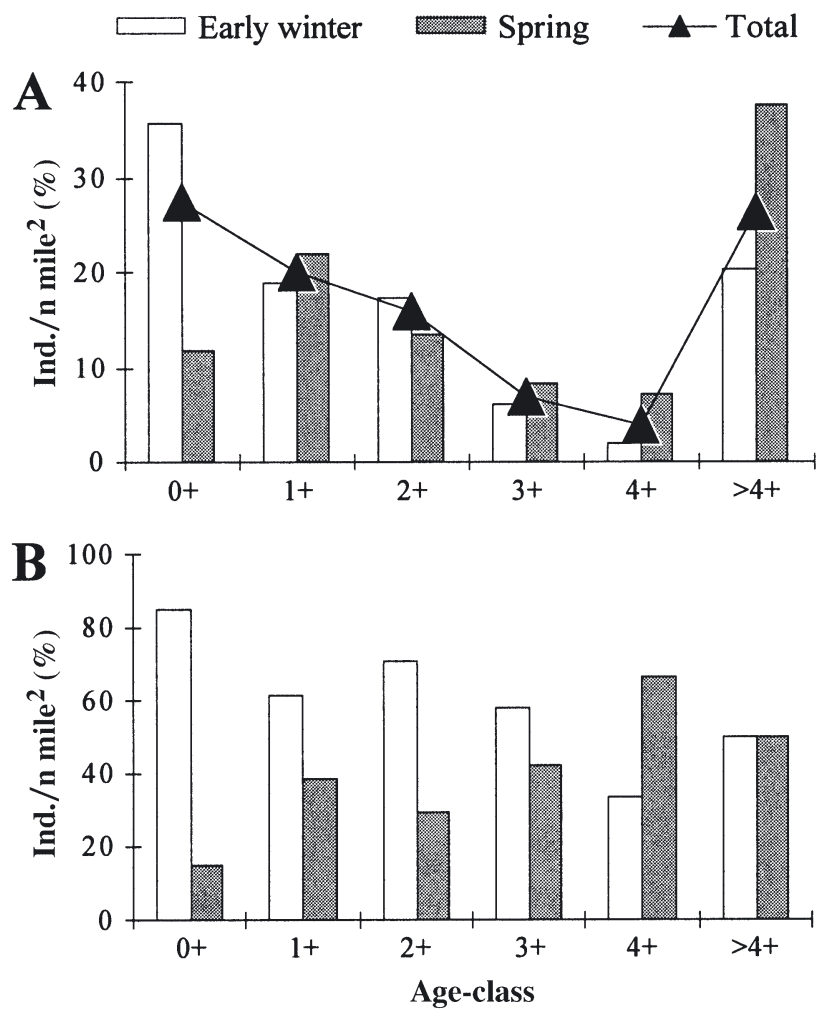

Fig. 2. Micropogonias furnieri. (A) Age-class structure of the population for the entire period analyzed, and for each season, (B) seasonal abundance of each age-class in the estuary

bottom salinity from 5 to 20 psu (between Punta Piedras and Montevideo) presented a strong horizontal gradient, bounded by regions with weaker gradients (Figs. 3C \& 4C) and it coincided with the Barra del Indio, a shallow area across the river (Fig. 1).

Satellite images showed a turbidity front distribution that followed the $5 \mathrm{~m}$ isobath in Samborombom Bay (Figs. 3D \& 4D), but differences between seasons arise when the inner zone of the estuary is considered. Although the general frontal area was coincident for both seasons with the Barra del Indio geometry across the river, in winter the front reached its easternmost location, and we frequently observed longitudinal fronts parallel to the Uruguayan coastline extending far from Montevideo (Fig. 3D). In the spring, less variability in the position of the front and a westward advance of the front was observed for the inner area (Fig. 4D). Longitudinal fronts on the northern coast eventually occurred, but also the westernmost positions of the turbidity distribution were registered in this area.

\section{Spatial distribution of age-classes and their relationship with environmental factors}

In both seasons, the DCCA revealed a pattern in the Micropogonias furnieri age-class distribution within the estuary, with several groups along the principal axis of the estuary (Fig. 5A,C). Age compositions (Figs. 5B,D \& 6) and environmental characteristics (Table 2) differed for each group.

\section{Early winter}

Four groups were defined by DCCA ordination (Fig. 5A). These groups represent different areas of the estuary: western inshore (WIS), eastern inshore (EIS), middle shore (MS) and offshore (OS) (Fig. 5B).

- WIS corresponds to the sampling stations of the inner zone of the estuary. It was characterized by a substrate of mud, the shallowest depths (mean $6.00 \mathrm{~m}$, $\mathrm{SD} 1.87$ ) and the minimum bottom salinity (mean $1.77 \mathrm{psu}, \mathrm{SD} 2.16$ ) (Table 2). Turbidity was high and persistent in this area, which was located shoreward of the turbidity front (Fig. 3D). The area contained primarily Age 0+ and Age 1+ whitemouth croakers (67.69 and $26.04 \%$, respectively) (Fig. 5B), and had the lowest abundance of adults (Age 4+, $0.67 \%$; Age $>4+, 1.4 \%$ ) (Fig. 6A).

- EIS also includes sampling stations of the inner zone, with substrate, depth and surface salinity similar to the west inshore area, and a higher bottom salinity
Table 2. Oceanographic data (mean $\pm \mathrm{SD}$ ) and substrate $(\%)$ for the areas defined by means of the detrended canonical correspondence analysis (DCCA). $\mathrm{Z}$ : depth $(\mathrm{m})$; ST: surface temperature $\left({ }^{\circ} \mathrm{C}\right) ; \mathrm{BT}$ : bottom temperature $\left({ }^{\circ} \mathrm{C}\right) ;$ SS: surface salinity (psu); BS: bottom salinity (psu)

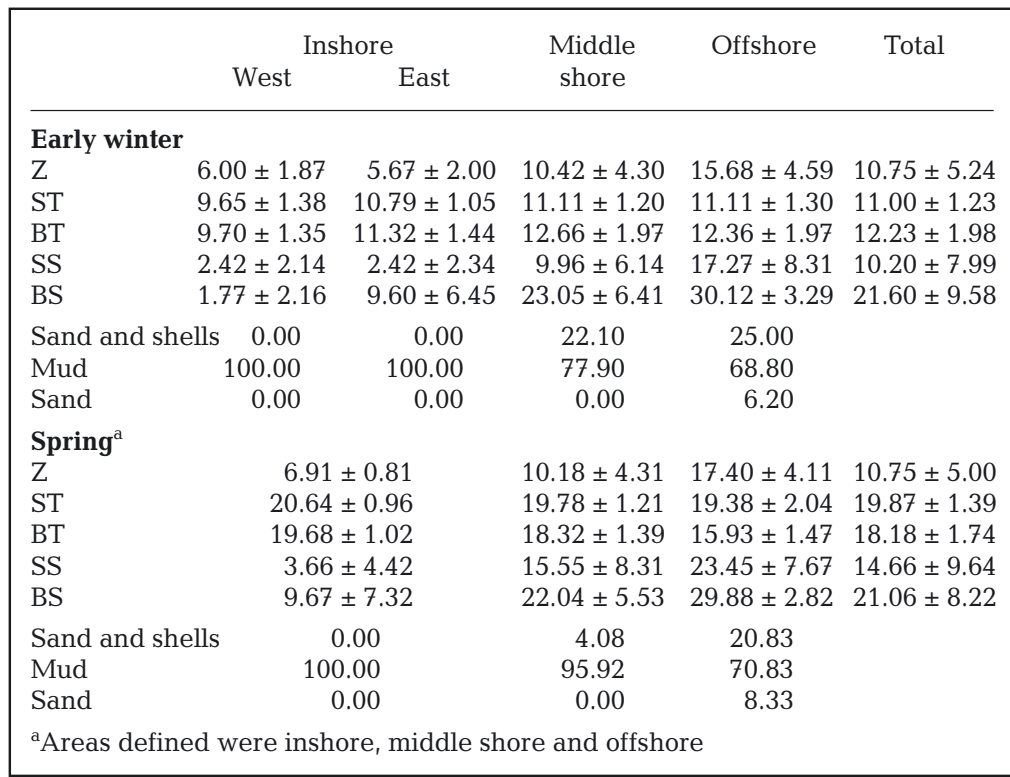



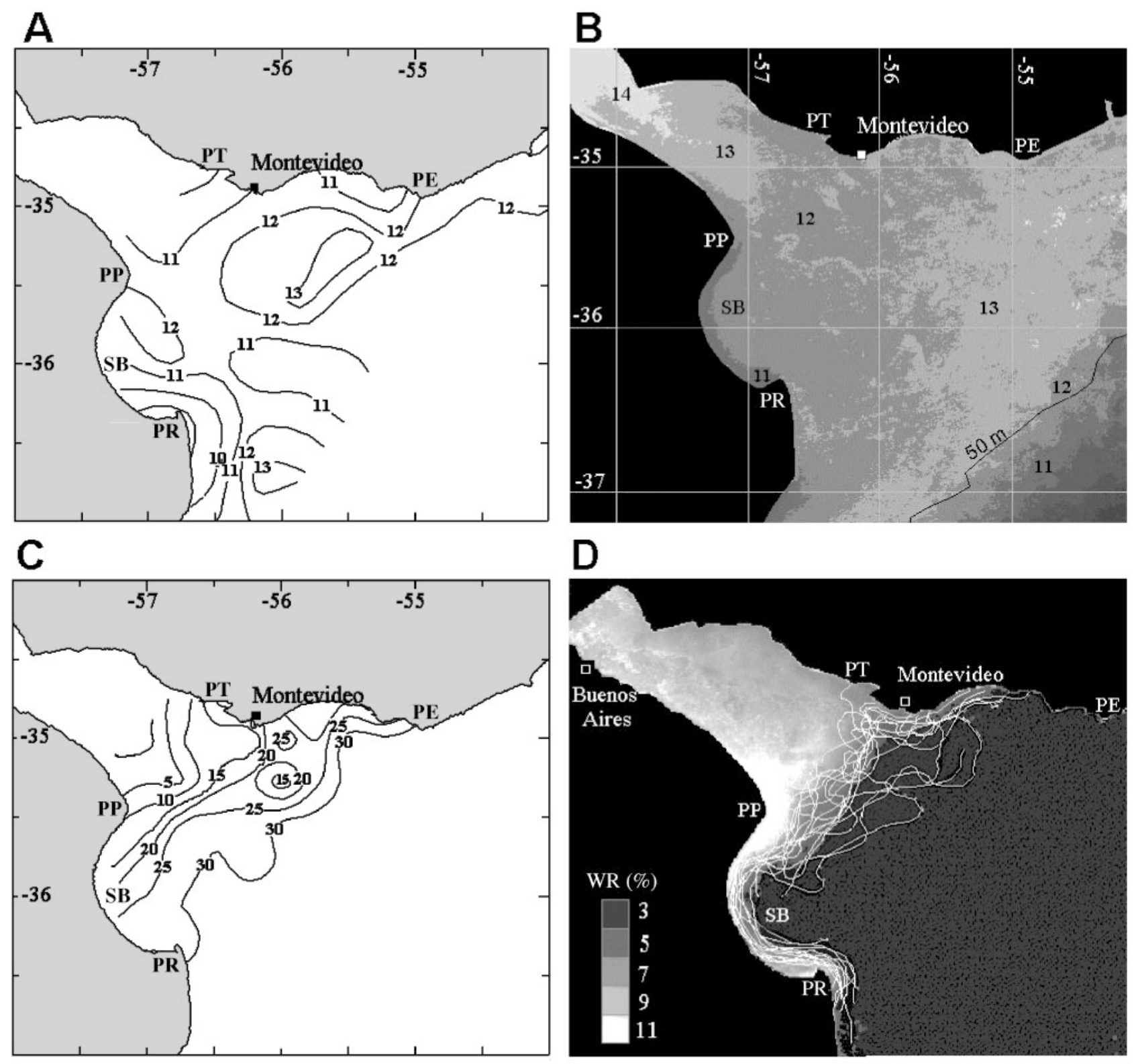

Fig. 3. Distribution of environmental parameters for early winter. (A) Bottom temperature $\left({ }^{\circ} \mathrm{C}\right)$, (B) surface temperature $\left({ }^{\circ} \mathrm{C}\right)$, (C) bottom salinity (psu), and (D) turbidity (WR = water reflectance). PE = Punta del Este, PP = Punta Piedras, PR = Punta Rasa, $\mathrm{SB}=$ Samborombon Bay, $\mathrm{PT}=$ Punta Tigre

(mean 9.60 psu, SD 6.44) (Table 2). The turbidity-front distribution was coincident with most of the sampling stations for this area (Fig. 3D). Ages 0+ and 1+ represented 68 and $20 \%$ of the age composition, respectively (Fig. 5B). This area also presented the highest abundance of Age 0+ whitemouth croaker juveniles $(56.3 \%)$ in the estuary (Fig. 6A).

- MS is defined by the intermediate depth (mean $10.42 \mathrm{~m}, \mathrm{SD}$ 4.30) and bottom salinity (mean $23.05 \mathrm{psu}, \mathrm{SD} 6.41)$. The substrate was principally mud (80\%) and shell (20\%) (Table 2). Sampling stations for this area occupied the turbidity front, but were also located in the outer area of the estuary
(Fig 3D). Age 2+ individuals dominated the age distribution (29.5\%) (Fig. 5B). Also, the highest abundance of Age 3+ individuals (55.08\%) within the estuary occurred in this area (Fig. 6A).

- OS corresponds to the deepest zone in the estuary (mean 15.68 m, SD 4.59), with bottom salinity over $30.1 \mathrm{psu}$ and a high diversity of substrates (mud $68.80 \%$, sand and shell $25.00 \%$, and sand $6.30 \%$ ) (Table 2). The turbidity front rarely reached this area (Fig. 3D), which contained principally whitemouth croaker adults up to $5 \mathrm{yr}$ old (Age $>4+, 55.51 \%$ ) (Fig. 5B), and also the lowest abundance of juveniles in the estuary (Fig. 6A). 

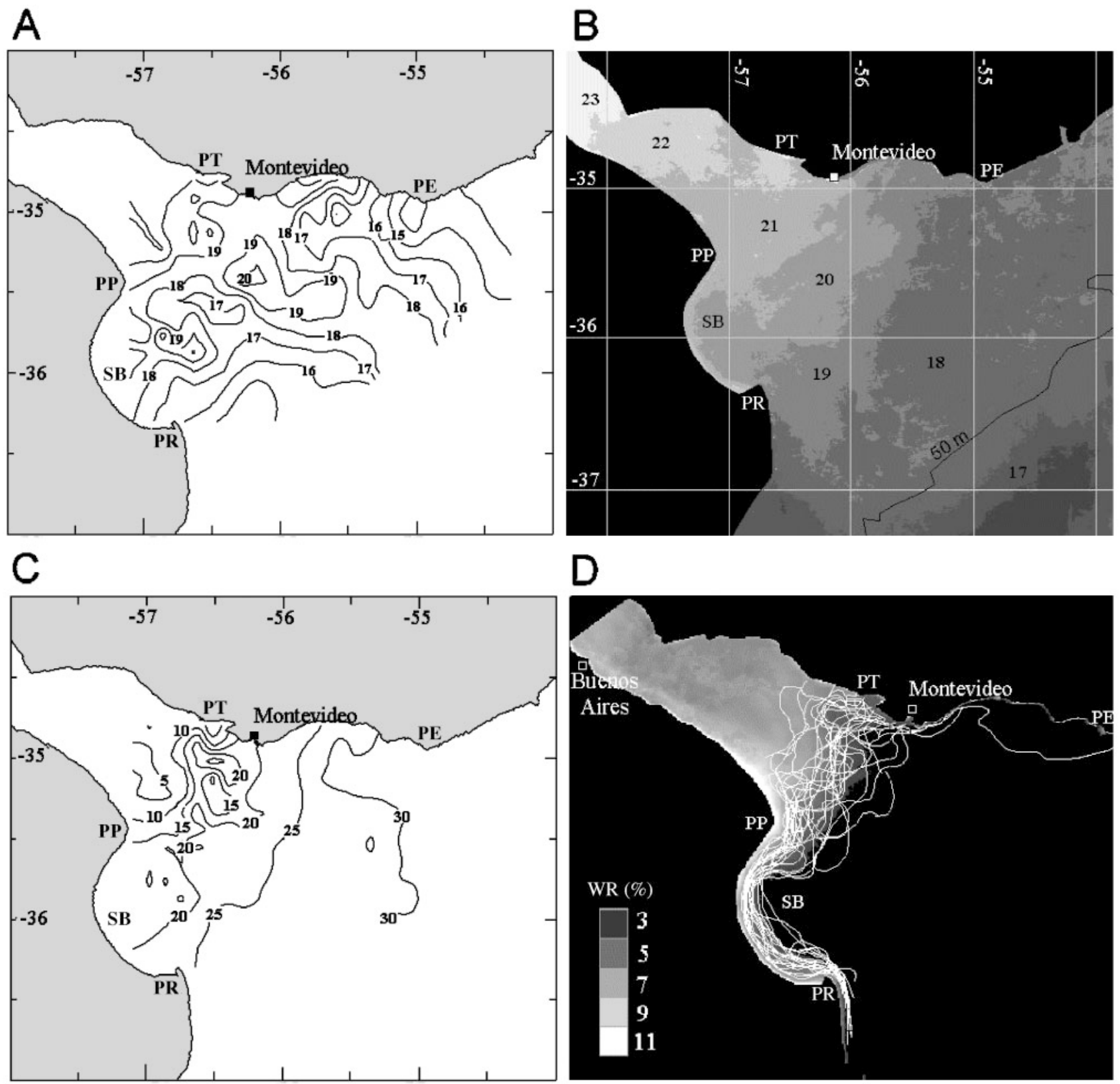

Fig. 4. Distribution of environmental parameters for spring. (A) Bottom temperature $\left({ }^{\circ} \mathrm{C}\right)$, (B) surface temperature $\left({ }^{\circ} \mathrm{C}\right)$, $(\mathrm{C})$ bottom salinity (psu), and (D) turbidity (WR = water reflectance). Abbreviations as in Fig. 3

The canonical coefficients for the first 2 axes of the DCCA, and the intra-set coefficients of the correlation between these axes and the environmental variables, indicate the importance of each environmental variable for each axis (Table 3). Both axes are obtained from the linear combination of environmental variables that maximize the dispersion of the sampling station scores derived from age scores. From the intra-set coefficients (Table 3), it is evident that bottom salinity was the most important factor in determining the spatial distribution pattern of Micro- pogonias furnieri age-classes (Fig. 5B). The second axis seems to be basically a temperature gradient (Table 3).

\section{Spring}

The DCCA ordination identified 3 principal groups of stations (Fig. 5B) designated as inshore area (IS), MS and OS (Fig. 4D). The spring groups showed broad similarities to those of early winter (Fig. 5A). 
- IS includes sampling stations of the inner zone. It was characterized by a substrate of mud $(100 \%)$, the shallowest depth range (mean $6.91 \mathrm{~m}, \mathrm{SD} 0.81$ ), and the minimum bottom salinity (mean 9.67 psu, SD 7.32) (Table 2). Almost all stations were located inside the turbidity front (Fig. 4D). Age 1+ individuals dominated the age composition $(50 \%)$, followed by Ages $0+$ and $>4+$ (18 and $17 \%$ respectively) (Fig. 5D). This area had the highest abundance of Age $0+$ and $1+$ whitemouth croaker juveniles (99 and $97 \%$ respectively) in the estuary (Fig. 6B).

- MS corresponds to the sampling stations of the central and inner zone of the estuary, with an intermediate depth (mean $10.18 \mathrm{~m}, \mathrm{SD} 4.31$ ) and bottom salinity (mean 22.04 psu, SD 5.53) (Table 2). Sampling stations of this area were located both inside the turbidity front and in areas outside the turbidity front (Fig. 4D). The substrate was principally mud $(95.92 \%)$, and shell and sand (4.08\%) (Table 2). Age $4+$ individuals dominated the age composition $(53 \%)$, followed by Age 2+ (19\%) (Fig. 5D). Also, the highest abundance of individuals older than Age 2+ within the estuary occurred in this area (Fig. 6B).

- OS is the deepest zone in the estuary (mean $17.40 \mathrm{~m}$, SD 4.11), with the highest bottom (mean $29.88 \mathrm{psu}_{\text {; }}$ SD 2.82) and surface (mean 23.45 psu, SD 7.67) salinity and a high diversity of substrate (mud $70.83 \%$, sand and shell $20.83 \%$, and sand $8.34 \%$ ) (Table 2). In general, sampling stations for this area were located far outside the turbidity front (Fig. 4D). Micropogonias furnieri individuals of Age-class $>4+$ were most prevalent in this area (98\%) (Fig. 5D), which is also characterized by the absence of Age $0+$ and $1+$ individuals (Fig. 6B).

The intra-set correlation of the environmental variables with the first 2 axes for the spring DCCA showed that bottom salinity was the most important factor in determining the spatial distribution pattern in this season (Fig. 4C), while the second axis was principally a depth and temperature gradient (Table 3).

\section{DISCUSSION}

The oceanographic conditions during cruises for all years considered in the present study were close to the mean conditions observed for winter and spring in other years (Guerrero et al. 1997a,b) and may be considered typical of these seasons for the estuary. The mean position of the bottom salinity front was located in a shallow area across the river along a line from Punta Piedras to Montevideo (Fig. 1), and was also coincident with the mean position given by Guerrero et al. (1997a). Satellite images showed spatial variability in the position of the turbidity front (Figs. 3D \& 4D); however, its position in both winter and spring of 1999 fits well with its location defined for the same seasons by Framiñan \& Brown (1996) using a dataset of images from 1986 to 1990.

Many authors have indicated that a zone of increased suspended particulate matter concentration, the estuarine turbidity maximum (ETM), takes place near the land-ward limit of the marine water intrusion (Dyer 1986, 1995, Grabemann \& Krause 1989). For the Río de la Plata estuary, Framiñan \& Brown (1996) have analyzed the correlation between salinity and turbidity-front distribution by computing a stratification parameter $(\Delta \mathrm{S} / \mathrm{h})$, which considers the bottom-surface salinity difference $(\Delta \mathrm{S})$ and the total depth $(\mathrm{h})$ for each point. The visual comparison between the distribution of this salinity intrusion index and density of the turbidity front inferred from satellite indicated that both parameters were correlated. Although turbidity images for this study only covered the last year of the cruise data, a very good visual correlation was seen in the figures for both seasons between the front positions of bottom salinity and surface turbidity.

Our results support the idea that different ageclasses of Micropogonias furnieri have different habitat preferences within the Rio de la Plata estuary, and that environmental factors play an important role in this habitat differentiation. Moreover, age-class composition showed changes in abundance between early winter and spring. The modal age-class was $0+$ in early winter, while fish older than 4 yr were the most abundant in spring. Although adults of $M$. furnieri are also common in continental shelf waters, the entire spawning cycle seems to occur within the estuary (Mianzan et al. 2001). Spawning, which takes place between November and April, occurs in the inner zone (Macchi \& Christiansen 1996) and coincides with the bottom salinity front (Macchi \& Christiansen 1996, Acha et al. 1999). Therefore, higher abundance of mature M. furnieri adults (older than $3 \mathrm{yr}$ ) during spring seems to be associated with reproductive movements from the outer estuary to the spawning areas.

The DCCA results indicate that bottom salinity has a significant influence on the spatial age-classes pattern, where the older age-class prefers the outer area (more saline) toward the mouth of estuary, while the youngest individuals inhabit the inner area (fresher water). Although the turbidity images are only available for the last year of the biological data, the turbidity front distribution fits well with the spatial ageclass pattern (Fig. 7) and with the salinity front. This spatial organization of Micropogonias furnieri coincides with the size distribution observed by Cousseau et al. (1986) and Diaz de Astarloa et al. (1997) in the estuary, and by Lasta (1995) in Samborombon Bay (Fig. 1). 

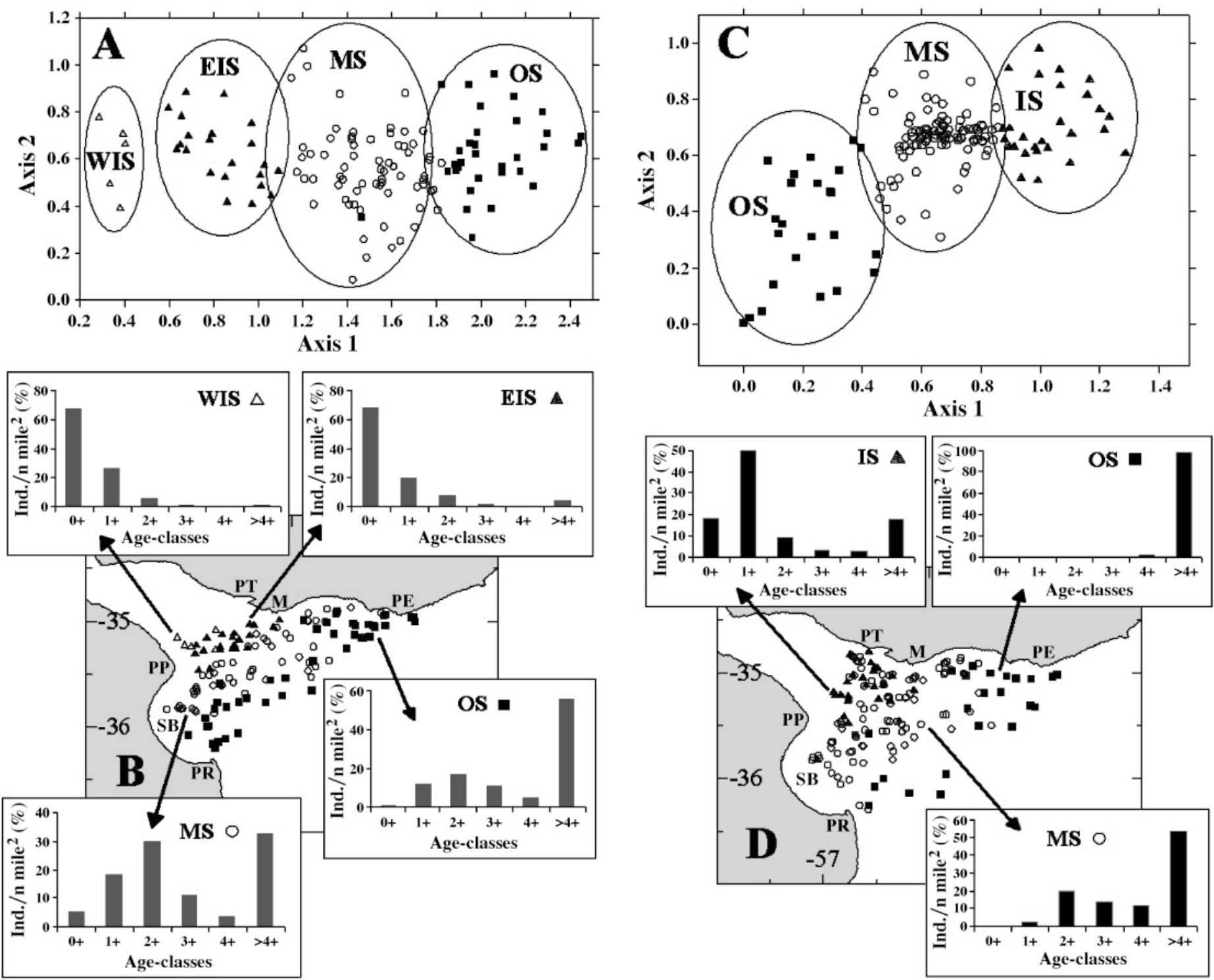

Fig. 5. (A) Detrended canonical correspondence analysis (DCCA) ordination diagrams corresponding to early winter showing defined groups of sampling stations: west inshore (WIS), east inshore (EIS), middle shore (MS) and offshore (OS). (B) Distribution areas for the early winter groups and Micropogonias furnieri age-classes. (C) DCCA ordination diagrams corresponding to spring showing defined groups of sampling stations: inshore (IS), MS and OS. (D) distribution areas for the spring groups and M. furnieri age-classes. $n$ mile: nautical mile

Similar patterns of distribution were found for this species in other coastal zones, as shown by Vazzoler (1991) for the estuarine lagoon region of Cananeia, central Brazil, and by Haimovici (1998) in the coastal ecosystem of southern Brazil. Castello (1986), working with croaker from the estuary of the dos Patos Lagoon, southern Brazil (Fig. 1), found out that small juveniles prefer waters less than $5 \mathrm{~m}$ depth, and larger individuals prefer deeper waters. On the shelf of Guiana, the adults of whitemouth croaker present a similar pattern; they inhabit deeper waters (>35 m), but juveniles live in tidal pools along the coast, generally away from estuaries (Lowe McConnell 1966). Also, in bays and estuarine zones of the northern hemisphere, Micropogonias undulatus shows the same pattern, such as in Rose Bay, Palmico Estuary (Miller et al. 1985) and in the Chumpam-Balchacah system (Ayala-Pérez et al. 1995), where juvenile croaker usually occupy shallow and low-salinity habitats.

The results of this study indicate that the young ageclasses of Micropogonias furnieri preferentially occupy the shallow waters at and above the salinity fronts in the estuary. Although turbidity images for this study only covered the last year of the cruise data, a very good coincidence was seen for both seasons between the frontal positions of bottom salinity and surface tur- 

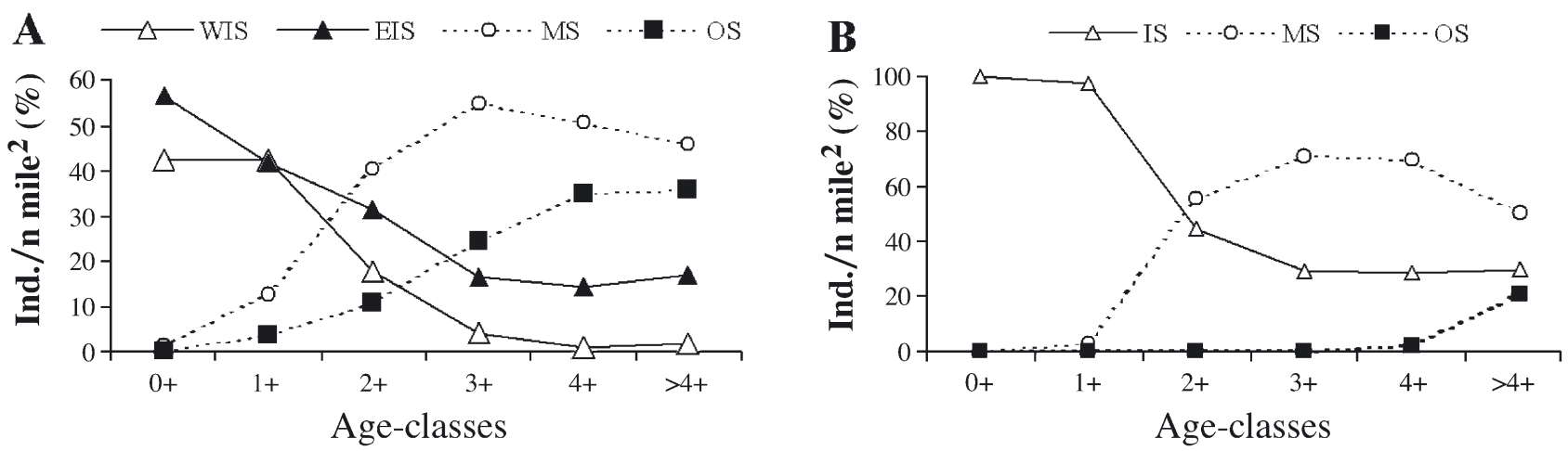

Fig. 6. Micropogonias furnieri. Observed age-class abundance ( $\%$ ind. $n$ mile ${ }^{-2}$ ) within the estuary for early winter (A) and spring (B). WIS: west inshore; EIS: east inshore; MS: middle shore; OS: offshore; IS: inshore. $n$ mile: nautical mile

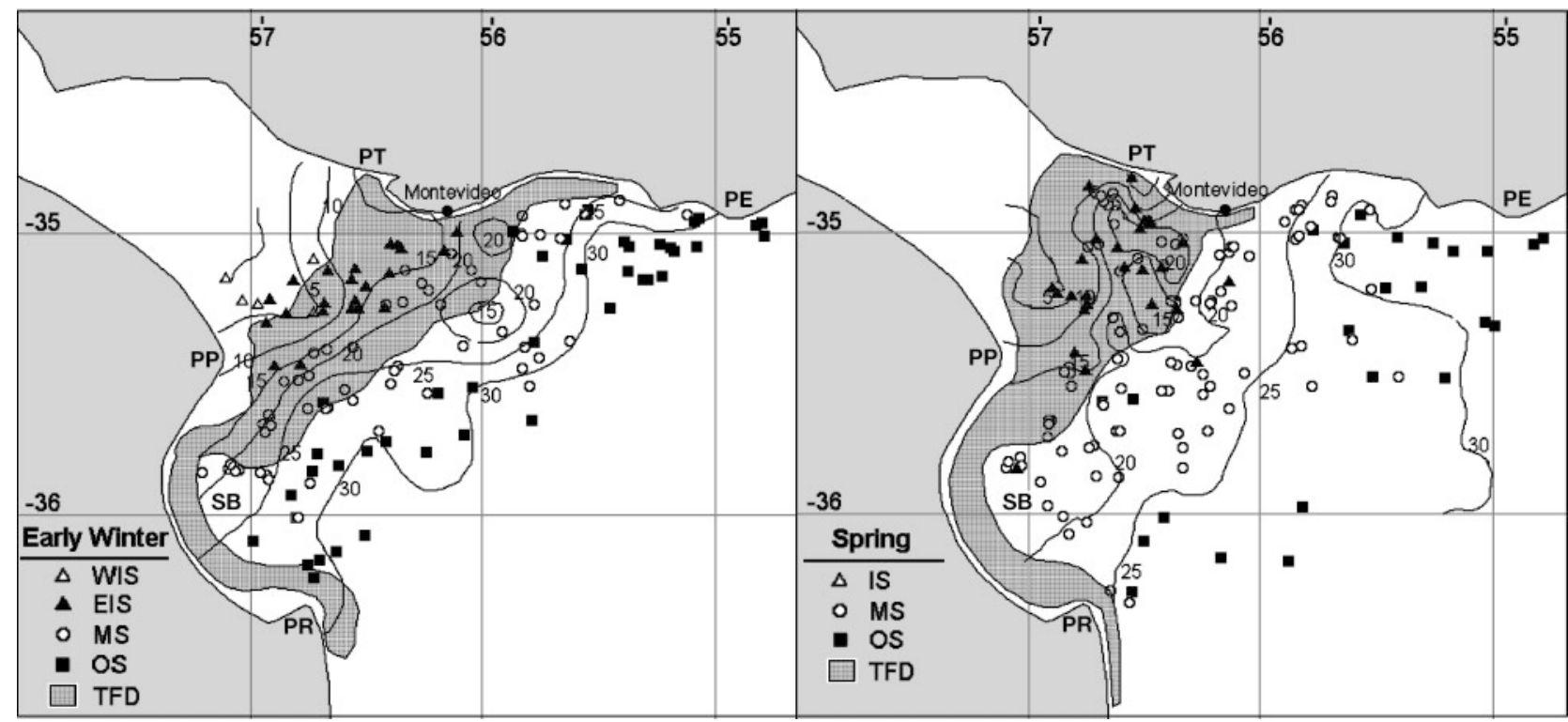

Fig. 7. Areas of distribution for the groups of sampling stations defined by DCCA analysis (Fig. 5) and turbidity frontal distribution within each season. WIS: west inshore; EIS: east inshore; IS: inshore; MS: middle shore; OS: offshore; TFD: turbidity frontal distribution

bidity (Figs. 3C,D \& 4C,D). The estuarine turbidity front also constitutes a region of high plankton concentration (Mianzan et al. 2001) and prey abundance (Giberto 2001, Dr. J. Ramirez pers. comm.) This ETM zone, with increased concentration of suspended particulate matter, may promote feeding aggregation by providing a visual contrast of prey items while at the same time reducing the predation risk for juvenile fish due to the high refuge provided by turbid conditions (Chesney 1989). The young age-classes of $M$. furnieri (Age $0+, 1+$ and $2+$ ) are an important prey for marine birds (Favero et al. 2000, 2001, Mauco et al. 2001). Based in the
Table 3. Canonical coefficients and intra-set correlation of the environmental variables with the first 2 axes of the detrended canonical correspondence analysis (DCCA). Z: depth (m); ST: surface temperature $\left({ }^{\circ} \mathrm{C}\right)_{i}$ BT: bottom temperature $\left({ }^{\circ} \mathrm{C}\right)$; SS: surface salinity (psu); BS: bottom salinity (psu); Spe-data: variance percentage of species data; Spe-env: variance percentage of species-environment relation

\begin{tabular}{|c|c|c|c|c|c|c|c|c|}
\hline \multirow[b]{3}{*}{ Variable } & \multicolumn{4}{|c|}{ Early winter } & \multicolumn{4}{|c|}{ Spring } \\
\hline & \multicolumn{2}{|c|}{ Coefficient } & \multicolumn{2}{|c|}{ Correlation } & \multicolumn{2}{|c|}{ Coefficient } & \multicolumn{2}{|c|}{ Correlation } \\
\hline & Axis 1 & Axis 2 & Axis 1 & Axis 2 & Axis 1 & Axis 2 & Axis 1 & Axis 2 \\
\hline Z & 2.97 & 5.09 & 0.69 & 0.07 & 8.29 & -7.43 & 0.74 & -0.49 \\
\hline ST & 1.10 & 6.76 & 0.27 & 0.37 & 6.66 & -3.80 & -0.41 & 0.03 \\
\hline BT & -4.31 & -3.17 & 0.45 & 0.17 & -9.54 & 15.22 & -0.72 & 0.42 \\
\hline SS & 7.80 & 0.74 & 0.69 & -0.24 & 11.18 & 1.56 & 0.80 & 0.30 \\
\hline BS & 22.77 & -20.32 & 0.91 & -0.33 & 18.02 & 17.61 & 0.92 & 0.38 \\
\hline Sand and shells & -15.36 & -7.21 & 0.16 & -0.21 & -2.00 & -6.45 & 0.29 & -0.20 \\
\hline Mud & -3.61 & -3.63 & -0.19 & 0.18 & -1.98 & -1.66 & -0.30 & 0.22 \\
\hline Sand & 0.13 & 0.93 & 0.13 & 0.09 & -0.08 & -1.44 & 0.11 & -0.15 \\
\hline Spe-data & 44.5 & 3.1 & & & 21.5 & 3.1 & & \\
\hline Spe-env & 88.3 & 5.7 & & & 80.3 & 16.1 & & \\
\hline Eigenvalue & 0.319 & 0.021 & & 0.201 & 0.030 & & & \\
\hline
\end{tabular}


persistence of young croaker distribution within this zone (Fig. 7), we suggest that the ETM is an important nursery area for this species, which could link the 2 main nursery areas of the estuary, Samborombon Bay and Santa Lucia River (beside Punta Tigre) (Fig. 7). The ETM has been found to be an important nursery area for larval fish in the St. Lawrence River estuary (Dodson et al. 1989), San Francisco Bay (Jabbsy et al. 1995) and Chesapeake Bay (North \& Houde 2001). As pointed out by Blaber \& Blaber (1980) and Cyrus \& Blaber (1987), although salinity may influence fish distribution in estuaries, the turbidity is more significant in relation to differential distribution patterns of young fish.

The low correlation between age-class and bottom sediment (Table 3) coincides with previous studies on feeding habits, where Micropogonias furnieri adults were characterized as generalist and opportunist predators. Given a generalist diet, food resources may not be limiting the distribution of white croaker. For this species, which inhabits waters with a wide salinity range (Rico 2000), the influence of salinity on the distribution is thought to be indirect. Therefore the observed distribution of adult age-classes in the offshore regions may be associated with other factors, such as a stress gradient along the estuary. It has been observed that samples taken in the inner region of the Río de la Plata estuary showed a decrease in immunoglobulin (IgM) concentration, which is an indicator of a depression in the capacity of inmunological response. This immunological depression can be associated with environmental stress (Romano et al. 1999). Romano et al. (1999) established that the IgM concentrations in the blood of $M$. furnieri adults caught in different regions of the estuary reflected various characteristics of water masses.

Although adults of Micropogonias furnieri are common toward the offshore regions, the entire spawning cycle seems to occur within the estuary (Mianzan et al. 2001). Spawning, which takes place between November and April, occurs in the inner zone (Macchi \& Christiansen 1996) and coincides geographically with the bottom salinity front (Macchi \& Christiansen 1996, Acha et al. 1999). This suggests that the greater abundance of $M$. furnieri adults during the spring seasons, and its higher penetration toward the inner area of the estuary could be associated with reproductive movements of adults from the outer zone to the spawning area. This spawning migration also coincides with the increase in size of the individuals captured by the artisanal fishery of Pajas Blancas (near Montevideo, Uruguay), in November and January (Norbis et al. 1992).

Besides influencing fish assemblage (Jaureguizar et al. 2001), salinity may affect the relative use of the estuary by age-classes of the same species. Some estu- arine species, such as Micropogonias furnieri, have different age-class distributions along the salinity gradient, and the influence of each age-class on the fish community structure would be distinct. Therefore, the species contribution to the average dissimilarity between zones of the estuary would differ for the various age-classes of the species. As a result, it seems clear that future considerations relative to spatial variations of assemblage structures in this and other estuaries should consider using age-classes of the same species as distinct taxa, as has been suggested by Able et al. (2001).

We have demonstrated that as a result of different habitat preferences shown by juvenile and adult Micropogonias furnieri, this species has an age-classspecific spatial distribution pattern within the Río de la Plata estuary. As the restriction of an age-class to only 1 environment implies a dependence on that environment, as suggested by Blaber et al. (1989), we feel that the ETM area represents an essential ecological habitat for this species. The area constitutes its principal spawning area in the region (Macchi \& Christiansen 1996, Acha et al. 1999) and, as has been shown here, also acts as a nursery area.

However, although we have defined the habitat boundaries as a function of the seasonal distribution of salinity and turbidity fronts, as well as of the observed daily variability of the turbidity front location (Framiñan \& Brown 1996), more specific studies comparing both cruise and satellite information for the same period are desirable. As the methodology for the atmospheric correction of the satellite images becomes available, turbidity (water reflectance) values from successive days could be incorporated as another variable within the multivariate analysis. This would allow us to establish the relative importance of both salinity and turbidity frontal distribution on the Micropogonias furnieri age-class distribution pattern within the Río de la Plata estuary.

The estuarine turbidity maximum area merits special care and protection, since it may be essential in regulating recruitment potential. Unfortunately, the 2 largest cities of Argentina and Uruguay, Buenos Aires and Montevideo, are located on the shores of the estuary, resulting in a high human impact. The identification of age-specific patterns (especially nursery areas) and their environmental determinants are becoming important tools for the management and protection of essential habitats and for maintaining sustainable fisheries. The present study allowed us to define the spatial boundaries for the distribution of various ages of whitemouth croaker in the Río de la Plata estuarine system. Such knowledge is prerequisite to establishing possible anthropogenic or environmental perturbation impacts on the young age-classes of this species. 
Acknowledgements. Thanks to Natalia Hozbor, Andrea Lopez Cazorla, Luis Lucifora and Kees Zwanenburg for many useful comments, to Raúl Guerrero for help in the oceanographic field and 3 anonymous referees for their comments on an earlier draft. Contribution INIDEP no. 1238.

\section{LITERATURE CITED}

Able KW, Nemerson DM, Busch R, Light P (2001) Spatial variation in Delaware Bay (USA) Marsh Creek Fish Assemblages. Estuaries 24(3):441-452

Acha EM, Mianzan H, Lasta CA, Guerrero RA (1999) Estuarine spawning of the whitemouth croaker Micropogonias furnieri (Pisces: Scianidae), in the Río de la Plata, Argentina. Mar Freshw Res 50:57-65

Ayala-Pérez LA, Pérez Velázquez A, Aguirre-Leon A, DíazRuiz S (1995) Abundancia nictemeral de corvinas (Pisces: Sciaenidae) en un sistema costero del sur del Golfo de Mexico. Hidriobiológica 5(1-2):37-44

Balay MA (1961) El Río de la Plata entre la atmósfera y el mar. Servicio de Hidrografía Naval, Buenos Aires, Publicación H-621

Blaber SJM, Blaber TG (1980) Factors affecting the distribution of juvenile estuarine and inshore fish. J Fish Biol 17:143-162

Blaber SJM, Brewer DT, Salini JP (1989) Species composition and biomasses of fishes in different habitats of a tropical northern Australian estuary: their occurrence in the adjoining sea and estuarine dependance. Estuar Coast Shelf Sci 29:509-531

Carozza CR, Cotrina CP (1998) Abundancia relativa y distribución de talla de Corvina rubia (Micropogonias furnieri) y Pescadilla de red (Cynoscion striatus) en la Zona Común de Pesca Argentino-Uruguaya y en El Rincón. Noviembre, 1994. In: Lasta CA (ed) Resultados de una campaña de evaluación de recursos demersales costeros de la Provincia de Buenos Aires y litoral Uruguayo. Noviembre, 1994. INIDEP Inf Téc 21:55-66

CARP (Comisión Administradora del Río de la Plata) (1989) Estudio para la evaluación de la contaminación en el Río de la Plata. Comisión Administradora del Río de la Plata, Montevideo-Buenos Aires, Informe de Avance

Castello JP (1986) Distribución, crecimiento y maduración sexual de la corvina juvenil (Micropogonias furnieri) en el estuario de la 'Lagoa Dos Patos', Brasil. Physis Buenos Aires 144(106):21-36

Chesney JR (1989) Estimation the food requirements of stripped bass larvae Morone saxalitilis: effects of light, turbidity and turbulence. Mar Ecol Prog Ser 53:191-200

Cotrina CP (1986) Estudios biológicos sobre peces costeros con datos de dos campañas de investigación realizadas en 1981. II. La corvina rubia (Micropogonias furnieri). Publ Com Tec Mix Frente Marit 1(1):8-14

Cotrina CP, Lasta C (1986) Estudio preliminar de la determinación de edad en la corvina (Micropogonias furnieri). Publ Com Tec Mix Frente Marit 1(2):311-318

Cousseau MB (1985) Los Peces del Río de la Plata y de su Frente Maritimo. In: Yañez-Arancibia A (ed) Fish community ecology in estuaries and coastal lagoons: towards an ecosystem integration. UNAM, México DF, p 515-534

Cousseau MB, Perrotta R (2000) Peces marinos de Argentina: biología, distribución, pesca. INIDEP, Mar del Plata

Cousseau MB, Cotrina CP, Cordo HD, Burgos GE (1986) Análisis de datos biológicos de corvina rubia (Micropogonias furnieri) y pescadilla de red (Cynoscion striatus) obtenidos en dos campañas del año 1983. Publ Com Tec Mix Frente Marit 1(2):319-332
Cyrus DP, Blaber SJM (1987) The influence of turbidity on juvenile marine fishes in estuaries. Part 1. Field studies at Lake St. Lucia on the southeastern coast of Africa. J Exp Mar Biol Ecol 109:53-70

Díaz de Astarloa JM, Carozza C, Guerrero RA, Baldoni AG, Cousseau MB (1997) Algunas características biológicas de peces capturados en una campaña costera invernal en 1993, en el área comprendida entre $34^{\circ}$ y $42^{\circ} \mathrm{S}$ (Atlántico Sudoccidental) y su relación con las condiciones ambientales. INIDEP Inf Téc 14:1-35

Dodson JJ, Dauvin JC, Ingram RG, d'Anglejan B (1989) Abundance of larval rainbow smelt (Osmerus mordax) in relation to the maximum turbidity zone and associated macroplankton fauna of the middle St. Lawrence estuary. Estuaries 12:66-81

Dyer KR (1986) Coastal and estuarine sediment dynamics. John Wiley \& Sons, New York

Dyer KR (1995) Sediment transport processes in estuaries. In: Perillo GM (ed) Geomorphology and sedimentology of estuaries. Developments in sedimentology, Vol 53. Elsevier Science, Amsterdam, p 423-449

Favero M, Silva MP, Mauco L (2000) Diet of royal and sandwich terns during austral winter at Buenos Aires Province, Argentina. Ornitol Neotrop 11:259-262

Favero M, Mariano-Jelicich R, Silva MP, Bó MS, Garcia-Mata C (2001) Food and feeding biology of black skimmer in Argentina: evidence supporting offshore feeding in nonbreeding grounds. Waterbirds 24:413-418

Framiñan MB, Brown OB (1996) Study of the Río de la Plata turbidity front. Part I. Spatial and temporal distribution. Cont Shelf Res 16(10):1259-1282

Framiñan MB, Etala MP, Acha EM, Guerrero RA, Lasta CA, Brown OB (1999) Physical characteristics and processes of the Río de la Plata estuary. In: Perillo GM, Piccocolo MC, PinoQuivira M (eds) Estuaries of South America, their geomorphology and dynamics. Springer-Verlag, Berlin, p 161-191

Gauch HG (1982) Multivariate analysis in community ecology. Cambridge University Press, New York

Giberto DA (2001) Fondos de alimentación de la corvina rubia (Micropogonias furnieri) en el estuario del Río de la Plata. BSc thesis, Universidad de Nacional Mar del Plata

Grabemann I, Krause G (1989) Transport processes of suspended matter derived from time series in a tidal estuary. J Geophys Res 94:14373-14379

Guerrero RA, Acha EM, Framiñan MB, Lasta CA (1997a) Physical oceanography of the Río de la Plata estuary, Argentina. Cont Shelf Res 17(7):727-742

Guerrero RA, Lasta CA, Acha EM, Mianzan H, Framiñan M (1997b) Atlas Hidrográfico del Río de la Plata. CARPINIDEP, Comisión Administradora del Río de la PlataInstituto Nacional de Investigacion y Desarrollo Pesquero (ed), Carcos SRL, Buenos Aires

Haimovici M (1998) Teleósteos demersais e bentonicos. In: Seeliger A, Odebrecht C, Castello JP (eds) Os ecossistemas costeiro e marinho do extremo sul do Brasil. Ecoscientia, Rio Grande, p 43-152

Haimovici M, Pereira SD, Vieira PC (1989) La pesca demersal en el sur de Brasil en el periodo 1975-1985. Frente Marit 5:151-161

Hozbor NM, García De La Rosa SB (2000) Alimentación de juveniles de corvina rubia (Micropogonias furnieri) en la laguna costera Mar Chiquita (Buenos Aires, Argentina). Frente Marit 18:59-70

Jabbsy AD, Kimmerer WJ, Monismith SG, Armor C, Cloern JE, Powell TM, Schubbel JR, Vendlinski TJ (1995) Isohaline position as a habitat indicator for estuarine populations. Ecol Appl 5:272-289 
Jaureguizar AJ, Menni R, Lasta C (2001) Asociaciones de Peces en el Estuario del Río de la Plata II. Patrones de distribución y factores ambientales. In: Asoc Argentina Ecología, Soc Chilena Ecología (eds) Libro de Resúmenes del $1^{\circ}$ Reunión Binacional de Ecología, 20 Reunión Argentina de Ecología y 10 Congreso de la Sociedad Chilena de Ecología. DANBAT Servicios Informáticos, San Carlos De Bariloche, p 138

Jongman RHG, ter Braak CJF, van Tongeren OFR (1995) Data analysis in community and landscape ecology. Cambridge University Press, New York

Lasta CA (1995) La Bahía Samborombón: zona de desove y cría de peces. PhD thesis, Universidad de Nacional de La Plata, La Plata del Plata

Lasta CA, Acha EM (1996) Cabo San Antonio: su importancia en el patrón reproductivo de peces marinos. Frente Marit 16:29-37

Lowe McConnell RH (1966) The sciaenid fishes of British Guiana. Bull Mar Sci 16(1):21-57

Macchi GJ, Acha EM (1998) Aspectos reproductivos de las principales especies de peces en la Zona Común de Pesca Argentino-Uruguaya y en El Rincón. Noviembre, 1994. In: Lasta CA (ed) Resultados de una campaña de evaluación de recursos demersales costeros de la Provincia de Buenos Aires y del litoral Uruguayo. Noviembre, 1994. INIDEP Inf Téc 21:67-89

Macchi GJ, Christiansen EH (1996) Análisis temporal del proceso de maduración y determinación de la incidencia de atresias en la corvina rubia (Micropogonias furnieri). Frente Marit 11:73-83

Mauco L, Favero M, Bó MS (2001) Food and feeding biology of the common tern (Sterna hirundo) in Samborombón Bay, Buenos Aires, Argentina. Waterbirds 24:89-96

Mianzan H, Lasta CA, Acha EM, Guerrero RA, Macchi G, Bremec C (2001) The Rio de la Plata estuary, ArgentinaUruguay. In: Seeliger U, de Lacerda LD, Kjerve B (eds) Ecological studies: coastal marine ecosystems of Latin America, Vol 144. Springer-Verlag, Berlin, p 185-204

Miller JM, Crowder LB, Moser ML (1985) Migration and uti-

Editorial responsibility: Otto Kinne (Editor),

Oldendorf/Luhe lization of estuarine nurseries by juvenile fishes: an evolutionary perspective. In: Rankin MA, Checkley D, Cullen J, Kitting C, Thomas P (eds) Migration: mechanisms and adaptive significance, Vol 27. Marine Science Institute, University of Texas, Austin, p 338-352

Norbis W (1995) Influence of wind, behaviour and characteristic of the croaker (Micropogonias furnieri) artisanal fishery in the Rio de la Plata (Uruguay). Fish Res 22: 43-58

Norbis W, Paesch L, Verocai J, Villamarin G (1992) Cambios en la estructura de la población de corvina rubia (Micropogonias furnieri) capturada en la pesquería artesanal de Pajas Blancas, Montevideo, Uruguay. Frente Marit 11: $37-45$

North EW, Houde ED (2001) Retention of white perch and striped bass larvae: biological-physical interactions in Chesapeake Bay estuarine turbidity maximum. Estuaries 24:756-769

Otero H, Ibañez PM (1986) Abundancia relativa de la corvina rubia (Micropogonias furnieri): modelos de producción excedente. Publ Com Tec Mix Frente Marit 1(2):341-350

Puig P (1986) Análisis de contenidos estomacales de corvina blanca (Micropogon operculatis) (Sciaenidae, Perciformes). Verano 1984. Publ Com Tec Mix Frente Marit 1(2): $333-340$

Rico R (2000) La salinidad y la distribución espacial de la ictiofauna en el estuario del Río de la Plata. BSc thesis, Universidad Nacional de Mar del Plata

Romano LA, Macchi GJ, Acha EM, Lasta CA (1999) Analysis of immunoglobulin concentration in the white croaker (Micropognias furnieri, Desmarest 1823) of the Rio de la Plata Estuary. Dev Comp Immunol 4:1-4

Sánchez F, Mari N, Lasta C, Giangiobbe A (1991) Alimentación de la corvina rubia (Micropogonias furnieri) en la Bahía Samborombón. Frente Marit 8:43-50

Vazzoler AEA de M (1991) Sintese de conhecimientos sobre a biologia da corvina, Micropogonias furnieri (desmarest, 1823), da costa do brasil. Atlántica, Rio Grande 13(1): $55-74$

Submitted: August 8, 2002; Accepted: February 20, 2003 Proofs received from author(s): May 22, 2003 